\title{
Active- and passive-avoidance learning in inbred mice: Transfer of training effects*
}

\author{
RICHARD L. SPROTT† and KAREN L. STAVNES \\ The Jackson Laboratory, Bar Harbor, Maine 04609
}

\begin{abstract}
The performance of four groups of mice of two genotypes (DBA/2J and C57BL/6J) was observed in two avoidance situations. Two groups, one of each strain, were given a maximum of 30 conditioning trials in an active avoidance situation followed by a maximum of 30 trials in a passive avoidance situation. The other two groups, one of each strain, were given passive avoidance conditioning first, followed by active avoidance conditioning. Positive transfer of training was observed in both genotypes for mice that received active avoidance conditioning prior to passive avoidance conditioning. Little or no transfer was observed from passive to active avoidan'e in either strain.
\end{abstract}

The use of avoidance paradigms in behavior genetic research is common and sometimes controversial (see Olton, 1973; Bolles, 1970). Most avoidance procedures can be classified as either active avoidance or passive avoidance on the basis of the E-defined criteria for learning in the experimental situation. In a passive avoidance procedure, the $S$ is required to inhibit a response, such as a jumping response, in order to avoid a noxious stimulus; in an active avoidance procedure, the $\mathrm{S}$ is required to emit a response, such as jumping to a safe area, in order to avoid the noxious stimulus. DBA/2J mice generally are viewed as active, jumpy mice, and might be expected to perform best in active avoidance situations where this trait provides a "natural advantage" and do poorly in passive avoidance situations. C57BL/6J mice, on the other hand, are generally classified as passive, and it therefore seems reasonable to assume that they would perform well in passive avoidance situations and poorly in active ones.

A number of investigators have reported differences in avoidance performance among inbred mouse strains (e.g., Carran, Yeudall, \& Royce, 1964; Royce \& Covington, 1960; Schlesinger \& Wimer, 1967; Wimer, Wymington, Farmer, \& Schwartzkroin, 1968). Evidence that at least some aspects of avoidance performance could be under single-gene control has been obtained in at least three laboratories (Oliverio, Eleftheriou, \& Bailey, 1973; Royce, Yeudall, \& Poley, 1971; Sprott, 1972).

A series of systematic studies has been conducted in this laboratory (Sprott, 1972, 1974) to assess the effects of genotype, age, and stimulus conditions upon the acquisition of a passive avoidance response in mice. Mice

*This investigation was supported by NIH Research Grant HD05523 from the National Institute of Child Health and Human Develo pment and Training Grant MH 12126 from the National Institute of Mental Health, and by an allocation from the George W. Perkins Memorial Foundation. The invaluable assistance of Jane Harris is gratefully acknowledged. The Jackson Laboratory is fully accredited by the American Association for Accreditation of Laboratory Animal Care.

$+R$ equests for reprints should be sent to Richard L. Sprott, The Jackson Laboratory, Bar Harbor, Maine 04609. of the DBA/2J strain appeared to perform this task best at shock levels of $1.0 \mathrm{~mA}$ or higher and the level of footshock appeared to be the major variable that affected performance. Mice of the $\mathrm{C} 57 \mathrm{BL} / 6 \mathrm{~J}$ strain appeared to perform this task best at very low levels of shock, particularly older mice. Thus, age and the level of footshock appeared to be determinants of the performance of C57BL/6 J mice (Sprott, 1972). Subsequent genetic analysis (Sprott, 1974) provided strong evidence that the strain difference in performance of this task was under the influence of a single locus, which has been designated Pp (passive performance).

The present experiments were designed to assess three questions. (1) Is the "passive performance" effect peculiar to passive situations or can it be demonstrated in active situations as well? (2) Can this effect be explained on the basis of an inherited activity level hypothesis? (3) Does learning an active response preclude learning a passive one and vice versa, or are more general "situational" responses acquired in these situations?

\section{METHOD}

\section{Subjects}

The Ss were 160 male mice from the $\mathrm{C} 57 \mathrm{BL} / 6 \mathrm{~J}(\mathrm{~B} 6, \mathrm{~N}=80)$ and DBA/2J (D2, $N=80$ ) strains. The mice were obtained from the Production Department of The Jackson Laboratory at 8 weeks of age and maintained in a research colony until 6 months of age ( \pm 6 days). Three days prior to the beginning of the experiment the Ss were transferred to a research colony room adjacent to the testing cubicle, weighed, ear punched, and placed on a $12-\mathrm{h} \operatorname{light} / 12-\mathrm{h}$ dark cycle. Mice were housed five per cage and given ad lib access to food (Old Guilford 911-R) and water.

\footnotetext{
Apparatus

The apparatus used for passive avoidance testing was identical to that described by Wimer et al (1968), while the apparatus used for active avoidance testing was a slight modification of that described by Wimer. The conditioning chamber was a $15.3 \times 15.9 \times 16.6 \mathrm{~cm}$ clear Plexiglas box with a stainless steel grid floor. The chamber could be modified for use in active or passive avoidance by changing the shelves mounted within the box. When used for passive avoidance, a $2.5 \times 13.5 \mathrm{~cm}$ removable black plastic shelf was mounted against one wall,
} 


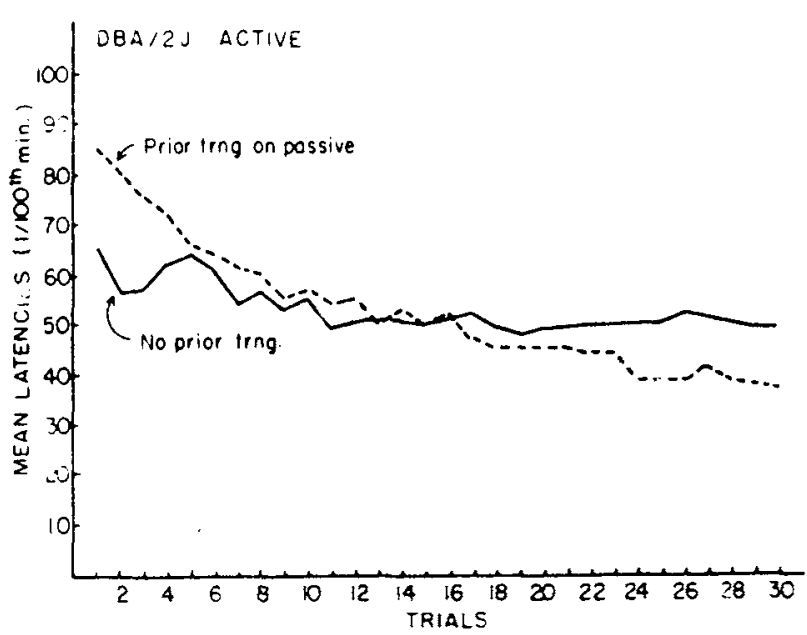

Fig. 1. Mean latencies to jump-up of $\mathrm{DBA} / 2 \mathrm{~J}$ mice in an active avoidance task with $(\mathrm{N}=39)$ and without $(\mathrm{N}=40)$ previous training in a passive avoidance task Latencies of $8 / 100$ ths min $(5 \mathrm{sec})$ are avoidance responses, while latencies longer than 8/100ths $\mathrm{min}$ are escape responses.

$2.2 \mathrm{~cm}$ above the grid floor. This platform could be folded up against one wall to prevent the S's return after it had stepped down. When used for active avoidance, a shelf $3.3 \mathrm{~cm}$ wide that ran around all four sides of the box was mounted $6 \mathrm{~cm}$ from the grid floor. Two small "ladders" fashioned from $1 / 4$-in. hardware cloth were attached to the shelf on opposite sides of the box. Each ladder was approximately $11 / 2 \mathrm{~cm}$ wide and hung down approximately $2 \mathrm{~cm}$ from the top of the shelf. Identical interchangeable boxes were used for active and passive testing. When a chamber was placed in position for testing, the grid floor was connected to a shock source and grid scrambler (Grason-Stadler E1064GS). The grid floor was designed so that shorting would not occur even if large quantities of water or urine were poured into the chamber. Meylan electric timers were used to measure latencies and to monitor the duration of footshock.

\section{Procedure}

All conditioning trials were conducted in a sound-attenuated testing cubicle, one trial each day, 5 days each week. Passive avoidance testing was conducted between the hours of $9 \mathrm{a} . \mathrm{m}$. and 11:30 a.m. and active avoidance testing was conducted between 12:30 p.m. and 3:30 p.m. One hour before the beginning of a testing session for a particular experimental group, the Ss were placed in individual numbered "milk-shake" cartons that were lined with cotton and had air holes punched in their tops. Each $\mathrm{S}$ was assigned a particular carton, and that carton was used for the duration of Phase I of the experiment. New cartons were assigned at the beginning of Phase II.

The experiment was divided into two phases: Phase I, original learning, and Phase II, transfer learning. The mice were divided into four groups of 40 mice each. One group of mice of each strain was given active avoidance conditioning and one group of each strain was given passive avoidance training during Phase I of the experiment. In Phase II of the experiment, mice which had been trained in the active avoidance situation were trained in the passive avoidance situation and vice versa. In all conditions (active or passive) and phases of the experiment, mice were given one trial each day until they reached criterion or a maximum of 30 trials. The chamber and grid were not cleaned between Ss, but boli were removed after each trial. The chamber was thoroughly washed using a strong detergent and a laboratory glassware cleaner at the end of each day.

Passive Avoidance Procedure. At the start of a conditioning trial, the $S$ was grasped gently by the tail, removed from its carton, and placed gently on the platform in the chamber. A 1-sec $0.1-\mathrm{mA}$ footshock was administered through the grid floor as soon as the S placed all four feet on the grid floor. At the same time, the shelf was rotated up against one wall of the box to prevent the $S$ from escaping the shock by returning to the shelf. After $1 \mathrm{~min}$ in the chamber, timed from placement on the shelf, the $S$ was grasped by the tail with forceps and returned to its carton. Ss were left in their cartons for $2 \mathrm{~h}$ and then returned to their home cages. Criterion was reached when the $S$ remained on the shelf for the full 60 -sec period for three consecutive trials. Individual Ss were not tested after they had reached criterion. During Phase I, all Ss in a single home cage were transferred to Phase II when all mice in that cage had reached criterion, and Phase II active training was begun on the next testing day.

Active Avoidance Procedure. The procedure for active avoidance was the same as that for passive avoidance with a few exceptions. Each trial consisted of a 5-sec avoidance period with no footshock and no E-arranged conditioned stimuli, followed by a maximum of $60 \mathrm{sec}$ of a $0.1-\mathrm{mA}$ footshock. The trial ended when the mouse avoided or escaped the shock by jumping to the shelf, or failed to escape the shock within the 60 -sec shock period.

During Phase I of the experiment (in both the active and passive conditions), the testing order within each strain was counterbalanced across housing in home cages. However, because training began in Phase II as soon as an entire home cage of mice had reached Phase I criterion, testing order was not counterbalanced across cages in Phase II. D2 mice were always tested before B6 mice. Each strain was tested in a separate, identical chamber.

All comparisons between the distributions of trials to criteria of experimental groups were evaluated with the Kolmogorav-Smirnov two-sample test (Siegel, 1956). Product-moment correlation coefficients were used to estimate correlations between active and passive performances (Hays, 1965). Trial 1 transfer effects were evaluated with student $t$ tests (Hays, 1965).

\section{RESULTS}

In the original learning phase of the experiment (Phase I), mice of both strains performed poorly in the active avoidance situation. Thirty-eight of $40 \mathrm{D} 2$ mice that were tested in the active situation in Phase I failed to reach criterion by Trial 30 . The performance of $\mathrm{B} 6$ mice was significantly better $(D=0.45$, criterion $D=$ $0.304, p<.05$ ) but still poor, as 20 of the 40 mice in this group failed to reach criterion by Trial 30 .

Mice of both strains that were tested in the passive situation in Phase I performed well. All mice of both strains reached criterion before Trial 25. Again B6 mice appeared to perform better than D2 mice, but this difference was not significant (mean number of trials to criterion: $\mathrm{B} 6=7.7, \mathrm{D} 2=9.1$ ).

In the "transfer of training" phase (Phase II), the results were similar to those obtained in Phase I: Mice tested in the active situation in Phase II performed very poorly. One D2 mouse died during Phase II active testing and his performance scores were removed from the data for both phases. All 39 of the remaining D2 mice in this group failed to reach criterion by Trial 30 . Since the overall performance of this group, which had passive training in Phase $I$, did not differ from the performance of the D2 mice tested in the active situation, it was evident that there were no positive transfer effects from passive training to active avoidance performance in D2 


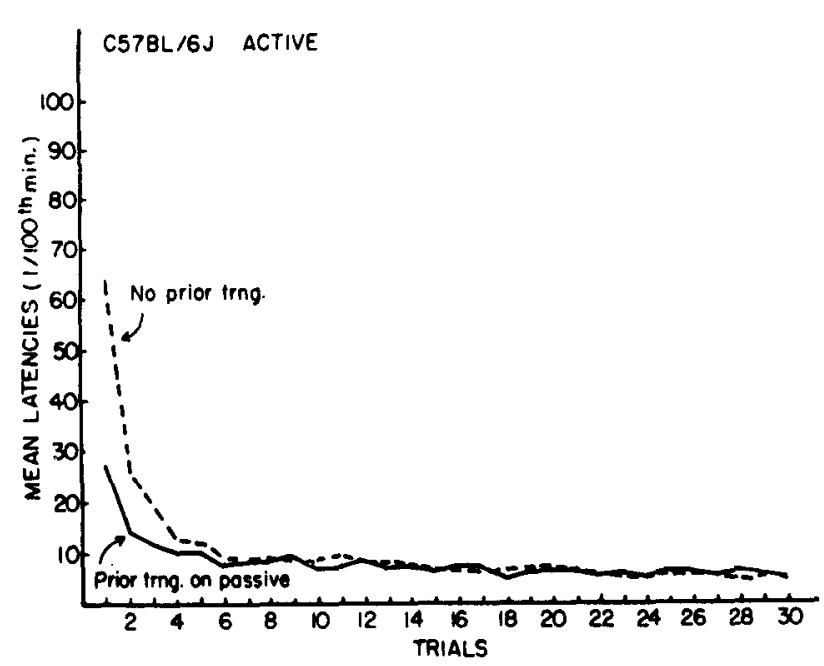

Fig. 2. Mean latencies to jump-up of $\mathrm{C} 57 \mathrm{BL} / 6 \mathrm{~J}$ mice in an active avoidance task with $(\mathrm{N}=40)$ and without $(\mathrm{N}=40)$ previous training in a passive avoidance task. Latencies of $8 / 100$ ths $\mathrm{min}(5 \mathrm{sec})$ are avoidance responses, while latencies bnger than $8 / 100$ ths $\mathrm{min}$ are escape responses.

mice. Since so few Ss in either D2 group reached criterion, the possibility of negative transfer effects could not be estimated. However, an examination of latency scores (Fig. 1) for these two groups suggests that if any negative transfer occurred, it was a negligible factor in D2 performance, confined to early trials. The latencies of the group with prior passive experience were significantly longer on Active Trial 1 than those of naive D2 mice $(t=2.36, d f=77, p<.025)$.

The performance of $\mathrm{B} 6$ mice tested in the active situation in Phase II was not significantly different from that of B6 mice tested in the active situation in Phase I. However, the performance of this group was significantly better than that of comparable D2 mice.

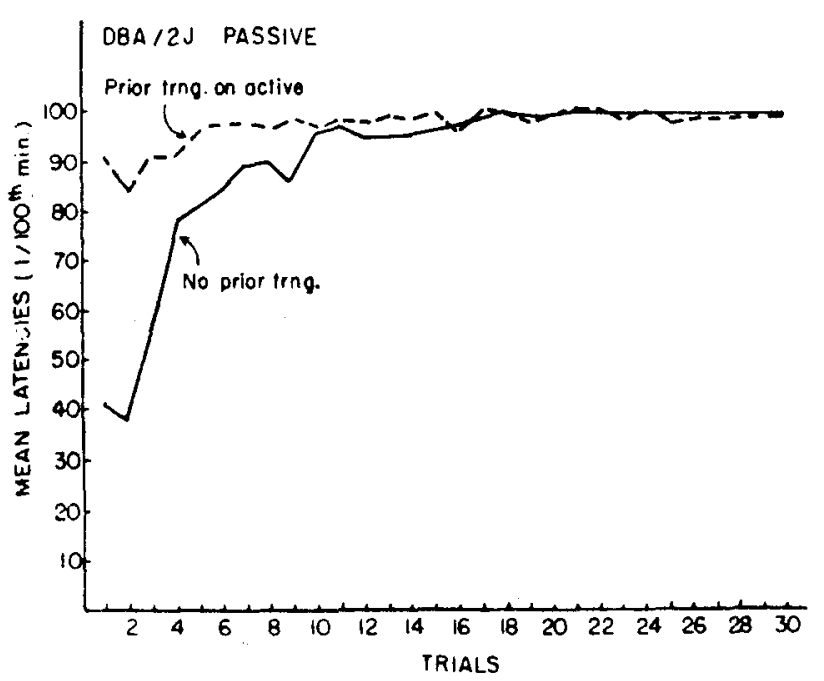

Fig. 3. Mean latencies to step-down of $\mathrm{DBA} / 2 \mathrm{~J}$ mice in a passive avoidance task with $(N=40)$ and without $(N=39)$ previous training in an active avoidance task. Latencies of $100 / 100$ ths $\min$ are successful avoidance responses.
Thus, prior training in the passive situation did not produce any major positive transfer effects in B6 mice. Examination of latency scores (Fig. 2) suggests that, if positive transfer occurred, its effects were minor and confined to the first few trials. Trial 1 latencies of the transfer group were significantly shorter than those of naive B6 mice $(\mathrm{t}=6.83, \mathrm{df}=78, \mathrm{p}<.001)$; however, the variances of the groups were unequal.

The performance of B6 and D2 mice tested in the passive situation, Phase II, was significantly better than that of comparable groups in Phase I (D2: D $=0.400$, criterion $\mathrm{D}=0.304, \mathrm{p}<.05$ ). As in Phase $\mathrm{I}$, the performance of the two strains did not differ with Phase II passive tests. Examination of latency scores (D2, Fig. 3; B6, Fig. 4) reveals a large positive transfer effect in the early trials. In fact, 29 D2 mice and 17 B6 mice reached criterion on Trial 3 and, therefore, never made an error in Phase II. Trial 1 latencies were significantly longer for the transfer groups than for the naive groups (B6: $t=7.31, \mathrm{df}=78, \mathrm{p}<.001 ; \mathrm{D} 2$ : $\mathrm{t}=9.32, \mathrm{df}=77, \mathrm{p}<.001)$.

A correlation coefficient was computed for each strain comparing trials to criterion for each mouse on active and passive tasks (Phase I and Phase II combined). These correlations were low in both strains (B6: $r=+.10 ; \mathrm{D} 2: \mathrm{r}=-.34$ ), indicating performance on one task could not consistently predict performance on the other task. The moderate correlation found for the D2 strain is most likely due to the fact that all but two of the mice did not reach criterion on the active avoidance task and, thus, were assigned a score of 30 trials to criterion, while nearly half of the D2 mice (the half previously trained on active) reached criterion on passive in three trials.

Correlations were also computed for B6 mice comparing the interval between the last trial on the

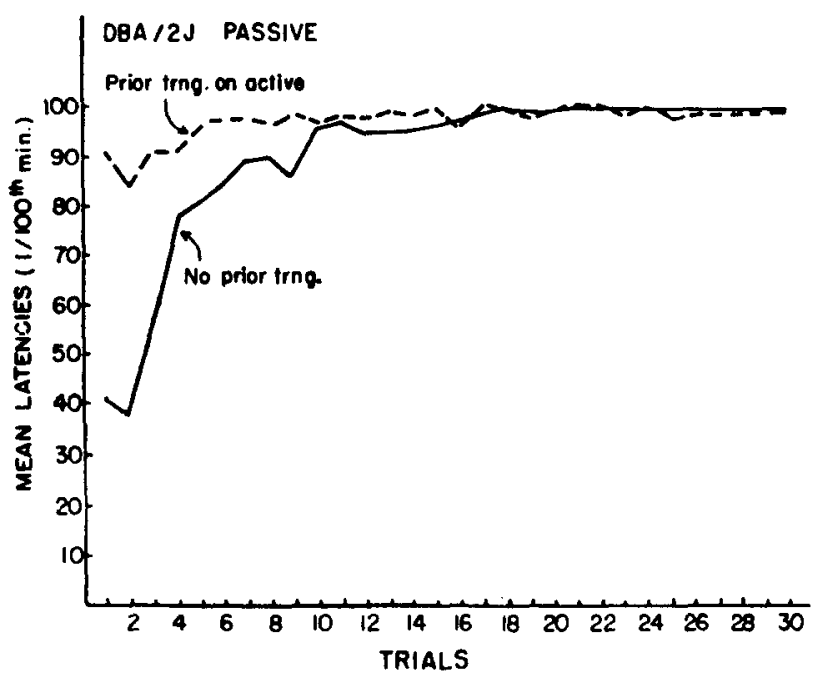

Fig. 4. Mean latencies to step-down of $\mathrm{C57BL} / 6 \mathrm{~J}$ mice in a passive avoidance task with $(N=40)$ and without $(N=40)$ previous training in an active avoidance task. Latencies of $100 / 100$ ths $\mathrm{min}$ are successful avoidance responses. 
passive task (Phase I) and the first trial on the active task (Phase II) to trials to criterion on the active avoidance task $(r=+.07)$, and comparing the interval between the last trial on the active task (Phase I) and the first trial on the passive task (Phase II) to trials to criterion on the passive avoidance task $(r=-.20)$.

In both cases the correlation was low, indicating the variance in the interval between Phase I and Phase II had little effect on the performance of B6 mice during Phase II. Similar correlations were not computed for D2 mice, since in the case where the mice were trained first in active avoidance (Phase I) and then in passive avoidance (Phase II), the interval between the two phases was 1 day for all mice except the two that reached criterion in active avoidance. In the second case, where the D2 mice were trained first on passive avoidance (Phase I) and then on active avoidance (Phase II), none of them reached criterion, so variance in the interval between the two phases had no effect on active avoidance performance.

\section{DISCUSSION AND CONCLUSIONS}

The results obtained in Phase I of this experiment are consistent with findings reported earlier (Sprott, 1972; Wimer et al, 1968). The performance of B6 mice was generally better than that of D2 mice, although the difference was small in the passive avoidance situation. The fact that the difference between D2 and B6 performance in Phase I passive performance was very small (and not significant) is probably due to the low level of footshock $(0.1 \mathrm{~mA})$ used in this experiment. These results also suggest that the genetic factors which influence passive performance (Sprott, 1972, 1974) may influence active performance as well.

The generally recognized difference in activity level (Wimer \& Fuller, 1966) between D2 (active) and B6 (passive) mice made an activity level hypothesis of genetic influence on avoidance performance an attractive possibility. This experiment was designed to provide a specific test of this hypothesis. If the gene or genes which influence passive avoidance performance, alleles at the Pp locus (Sprott, 1974), do so by determining the "natural" activity level of mice, then D2 mice should perform best in active avoidance situations and B6 mice should perform best in passive situations. Further, if activity level is a major determinant of performance, then it seems reasonable to predict negative transfer in both active and passive avoid ance training in Phase II of this experiment. Therefore, the results of this experiment provide very strong evidence that an activity level hypothesis is not tenable. The strongest effect observed was positive transfer from original learning in active avoidance to subsequent learning in passive avoidance. These results suggest that "situational" responses (e.g., a shelf is a safe location) are acquired rather than specific motor responses (e.g., freeze on shelf or leap to shelf). The fact that this transfer effect was equally large in both strains suggests that neither activity level nor ability to learn appropriate "situational" responses can account for the differences in the performance of these mice.

The very poor performance of all four groups in the active avoidance situation suggests that this task may be more difficult than the passive task. Observation of the Ss' behavior also suggested that the shock level $(0.1 \mathrm{~mA})$ was not high enough to motivate the Ss to perform the more difficult jump-up response. It seems reasonable to expect more positive transfer from a difficult task to an easier one than the reverse. The results of this experiment are consistent with this interpretation. Further, earlier experiments demonstrated that B6 mice perform better (are more motivated?) than D2 mice at low shock levels (Sprott, 1972). Therefore, the somewhat better performance of C57BL/6J mice in the passive situation, with or without prior experience, suggests that the low shock level may also have been a contributor to the poor active performance in this experiment.

Finally, the present experiment demonstrates that genetically controlled populations of mice can be used in combination with standard learning techniques to test specific hypotheses about the nature of gene action on behavior. The process is not a quick or easy one, however, and many such hypotheses may have to be tested before the pathway of such gene action, even in a relatively simple single-gene situation, is understood.

\section{REFERENCES}

Bolles, R. C. Species-specific defense reactions and avoidance learning. Psychological $R$ eview, 1970, 77, 32-48.

Carran, A. B., Yeudall, L. T., \& Royce, J. R. Voltage level and skin resistance in avoid ance conditioning of inbred strains of mice. Journal of Comparative \& Physiological Psychology, 1964, 58, 427-430.

Hays, W. L. Statistics for psychologists. New York: Holt, Rinehart, \& Winston, 1965.

Oliverio, A., Eleftheriou, B. E., \& Bailey, D. W. A gene influencing active avoidance performance in mice. Physiology \& Behavior, 1973, 11, 497-501

Olton, D. S. Shock-motivated avoidance and the analysis of behavior. Psychological Bulletin, 1973, 79, 243-251.

Royce, J. R., \& Covington, M. Genetic differences in the avoidance conditioning of mice. Journal of Comparative \& Physiological Psychology, 1960, 53, 197-200.

Royce, J. R., Yeudall, L. T., \& Poley, W. Diallel analysis of avoidance conditioning in inbred strains of mice. Journal of Comparative \& Physiological Psychology, 1971, 76. 353-358.

Schlesinger, K., \& Wimer, R. E. Genotype and conditioned avoidance learning in the mouse. Journal of Comparative \& Physiological Psychology, 1967, 63, 139-141.

Siegel, $\mathbf{S}$. Nonparametric statistics for the behavioral sciences. New York: McGraw-Hill, 1956.

Sprott, R. L. Passive avoidance conditioning in inbred mice: Effects of shock intensity, age, and genotype. Journal of Comparative \& Physiological Psychology, 1972, 80, 327-334.

Sprott, R. L. Passive-avoidance performance in mice: Evidence for single-locus inheritance. Behavioral Biology, 1974, in press.

Wimer, R, E., \& Fuller, J. L. Patterns of behavior. In E. L. Green (Ed.), Biology of the laboratory mouse. New York: McGraw-Hill. 1966. Pp. 629-653.

Wimer, R. E., Symington, L., Farmer, H., \& Schwartzkroin, P. Differences in memory processes between inbred mouse strains C57 BL/6J and DBA/2J. Journal of Comparative \& Physiological Psychology, 1968, 65, 126-131. revision accepted April 25, 1974.) 